\title{
Redesigning layout in the palm oil tank plant to enhance the utility
}

\author{
Anita Christine Sembiring ${ }^{1 *}$, Irwan Budiman ${ }^{1}$, and Hardianta Tarigan ${ }^{1}$ \\ ${ }^{1}$ Universitas Prima Indonesia, Industrial Engineering Department, Indonesia
}

\begin{abstract}
Material transfer is one of the most important activities in the production process activities and has a close relationship with the design of the layout of production facilities. A manufacturing company engaged in the manufacture and assembly of machine spare parts at the oil palm plant constraints in terms of material handling so that the decline in utility of the production floor layout and the increasing cost of moving raw materials. To improve the utility on the production floor using group technology method that is Rank Order Clustering (ROC) and Similarity Coefficient (SC). From the result of matrix rank calculation in pairs or between machines then SC method is the best layout design with decreasing material displacement moment by $56,86 \%$. And to improve the layout of facilities on the production floor using BLOCPLAN algorithm that is the value of the degree of Adjency Score of 0.5317 . This proposed layout provides a smaller displacement moment so as to shorten the processing time of all parts by 338 minutes and increase utility on the production floor.
\end{abstract}

\section{Introduction}

Material transfer is one of the most important activities in a production process and has a close relationship with the design of the production layout [1]. A manufacturing company engaged in the manufacture of machine spare parts and engine assembly used in oil palm factories has low utility constraints on the production floor associated with the completion of the product in accordance with predetermined targets.

The work of designing a facility usually begins with an analysis of the product to be made, or services to be delivered and a calculation of the flow of goods or activities as a whole. The detailed planning of the equipment arrangement, the interrelationship between the designed workplace, the closely related area grouped and then woven into a final layout [2-3].

Material transfer is one of the most important activities in the production process activities and has a close relationship with the design of the layout of production facilities. Moving material activities in certain industries can reach $50 \%$ to $70 \%$ of production costs. This activity itself is actually an activity that is classified as "non-productive" because it does not provide the added value of material or material being removed. Here there is no change in the shape, dimensions or physical or chemical properties of the material being removed. On the other hand, precisely the activity of moving the material will increase the cost. Many studies have reviewed the redesign on the production floor to minimize the distance and cost of material handling [4-9].

Based on the background that has been described previously, the problem to be solved in this research is the inefficiency of working hours in the production department so that it does not meet the set targets for some parts produced. This indicates that work activities are still not effective in providing output to the company, so it is necessary to do an analysis to determine the cause of inefficiency on the production floor in order to take corrective action in order to achieve the utility of the factory.

In this research, the authors will improve the layout of the facility on the current conditions in an effort to increase utility on the production floor by rearranging the facility layout based on the degree of closeness of the relationship between all activities on the production floor using the BLOCPLAN method. The purpose of this improvement is to provide a minimum material or material transfer moment and shorten production time between the workstation or machine and increase utility on the production floor [10-15].

\footnotetext{
* Corresponding author: anitakembaren $@$ unprimdn.ac.id
} 


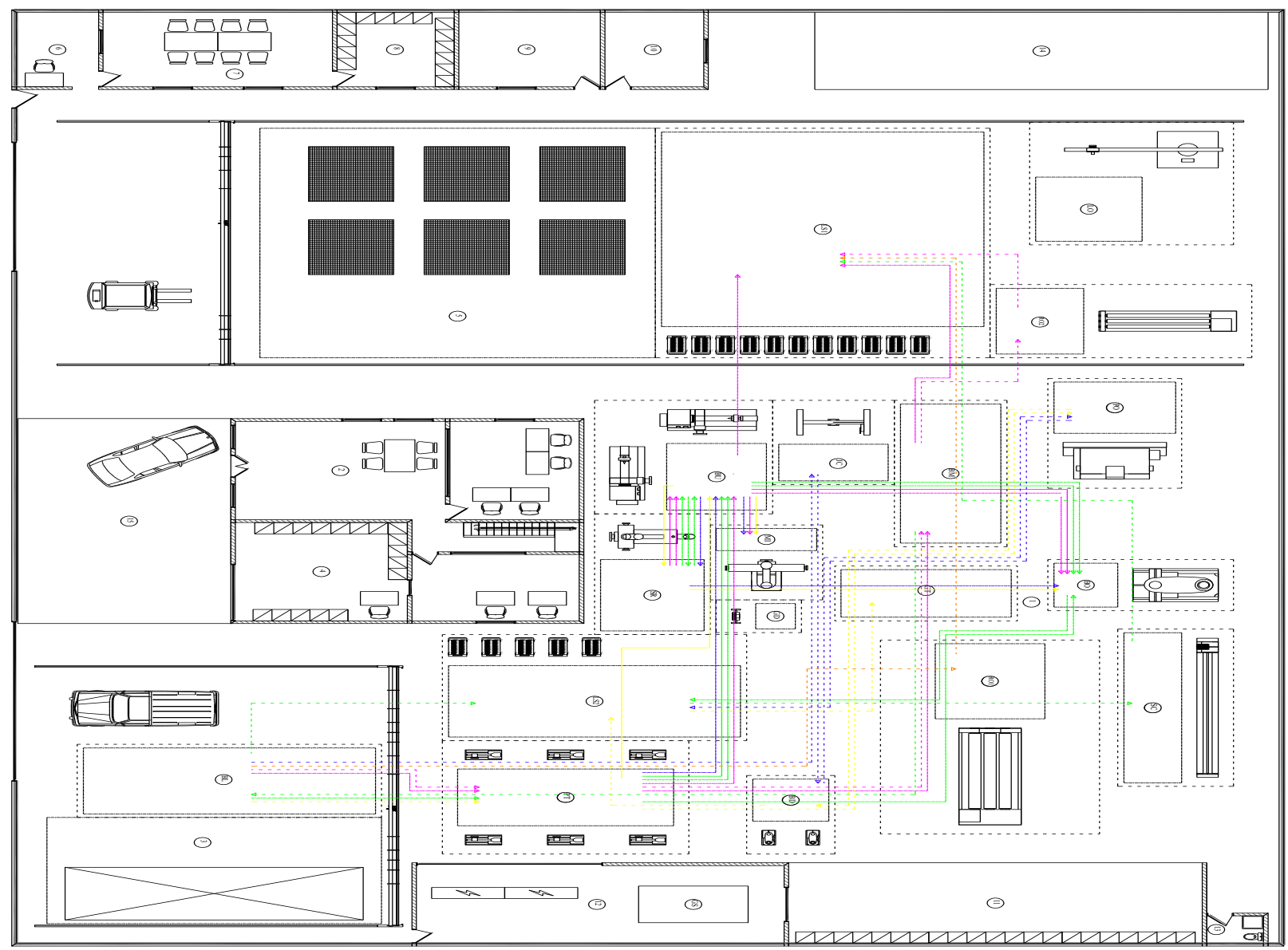

Fig. 1. Initial Layout.

\section{Methodology}

The research method used is action (Action Research), because it aims to get a better layout. This research starts with seeing the symptoms of problems that exist, then formulated the problems and objectives of this study. The final result of this research is the layout design based on the minimum displacement moment.

The group technology approach was first introduced by Burbidge in 1971 and Mitrofanov in 1966. Mitrofanov describes group technology as follows: Group technology is a reality that shows that many problems share similarities and by grouping similar problems, solving can be found for a set of problems, thus saving time and effort.

The settlement used in this study is to use ranking grouping algorithm or Rank Order Clustering (ROC) set the binary value for each row and column, rearrange rows and columns based on their binary value order and then find the group and Algorithm of equation coefficient or Similarity Coefficient (SC) is derived from numerical taxonomy and attempts to measure the coefficient equation (SC) between pairs or parts of machines. Most SC algorithms use the Jaccard equation (Sneath and Sokal, 1973). For machine pairs, the Jaccard coefficient can be described as the sum of the type of part visited by both machines divided into the number of sections visited by at least one machine.

\footnotetext{
* Corresponding author: anitakembaren $@$ unprimdn.ac.id
}

The arrangement of production floor facilities using the BLOCPLAN algorithm is a facility layout design system developed by Donaghey and Pire at the Department of Industrial Engineering, University of Houston. This program creates and evaluates layout types in response to input data. BLOCPLAN can use linkage as input data. The cost of layout can be measured either by distance size or by proximity. The number of rows inside BLOCPLAN is determined by the program and usually two or three rows. BLOCPLAN also has a drawback that will not capture the layout accurately. Layout development can only be searched by making changes or exchanges of departments one with the other. In addition to the linkage map BLOCPLAN, sometimes also use other input data from-to-chart maps, only the two input only used one course when doing layout evaluation.

The stages used in this study are:

- Calculating the distance between workstations in the initial layout,

- Determining the frequency of transfer material between workstations in initial layout,

- Determination of material handling moment in initial layout,

- The formation of the layout of the proposed production floor with Similarity Coefficient (SC),

- Determination of material handling moment in proposal layout

- Formation layout with Algorithm BLOCPLAN 


\section{Result and discussion}

This research is done by manufacturing company of manufacture of spare parts of palm oil mill machine, in production department which make 17 item of product that is cages, cages chasis, cages shaft, bushing house for cages, wheel for cages, shell plate for sterilizer, screw for conveyor, hanger, hanger bearings, joint shaft for screw conveyor, screw conveyor end shaft, bucket for bucket elevator, drive shaft for bucket elevator, sprocket for bucket elevator, scrapper for conveyor, drive shaft for scrapper conveyor and sprocket for scrapper conveyor.

Formation of initial matrix begins with the numbering of machines and components first, this is done to facilitate the making of the initial matrix.

Table 1. Numbering machines and components.

\begin{tabular}{|c|c|c|c|}
\hline Part & Part Code & $\begin{array}{l}\text { Type of } \\
\text { Machine }\end{array}$ & $\begin{array}{l}\text { Machine } \\
\text { Code }\end{array}$ \\
\hline Cages & LR1 & $\begin{array}{l}\text { Gas Cutting } \\
\text { Machine }\end{array}$ & $\mathrm{BL}$ \\
\hline Cages Chassis & LR2 & $\begin{array}{l}\text { Automatic } \\
\text { Shearing } \\
\text { Machine }\end{array}$ & $\mathrm{PO}$ \\
\hline Cages Shaft & LR3 & $\begin{array}{l}\text { Grinding } \\
\text { Machine }\end{array}$ & PT1 \\
\hline $\begin{array}{l}\text { Bushing House } \\
\text { for Cages }\end{array}$ & LR4 & $\begin{array}{l}\text { Cutting saw } \\
\text { Machine }\end{array}$ & PT2 \\
\hline Wheel for Cages & LR5 & $\begin{array}{l}\text { Rolling } \\
\text { Machine } \geq 18 \\
\text { mm }\end{array}$ & RO1 \\
\hline $\begin{array}{l}\text { Shell Plate for } \\
\text { Sterilizer }(3,8 \\
\text { meter) }\end{array}$ & ST1 & $\begin{array}{l}\text { Rolling } \\
\text { Machine } 10 \\
\mathrm{~mm}\end{array}$ & $\mathrm{RO} 2$ \\
\hline $\begin{array}{l}\text { Screw for } \\
\text { Conveyor ( } 2 \\
\text { meters) }\end{array}$ & $\mathrm{SC} 1$ & $\begin{array}{l}\text { Boring and } \\
\text { Tapping } \\
\text { Machine }\end{array}$ & $\mathrm{BO}$ \\
\hline $\begin{array}{l}\text { Hanger Bearing } \\
\text { Holder }\end{array}$ & $\mathrm{SC} 2$ & $\begin{array}{l}\text { Bench } \\
\text { Drilling } \\
\text { Machine }\end{array}$ & $\mathrm{BD}$ \\
\hline Hanger Bearing & $\mathrm{SC} 3$ & $\begin{array}{l}\text { Magnetic } \\
\text { Drill Machine }\end{array}$ & $\mathrm{BM}$ \\
\hline $\begin{array}{l}\text { Shaft Joint for } \\
\text { Screw Conveyor }\end{array}$ & $\mathrm{SC} 4$ & $\begin{array}{l}\text { Screw } \\
\text { Conveyor }\end{array}$ & $\mathrm{SC}$ \\
\hline $\begin{array}{l}\text { Screw Conveyor } \\
\text { End Shaft }\end{array}$ & SC5 & $\begin{array}{l}\text { Jack Pressure } \\
\text { Machine }\end{array}$ & $\mathrm{JC}$ \\
\hline $\begin{array}{l}\text { Bucket for } \\
\text { Bucket Elevator }\end{array}$ & BE1 & Grinder Hand & GT \\
\hline $\begin{array}{l}\text { Drive Shaft for } \\
\text { Bucket Elevator }\end{array}$ & BE2 & Grinder Sit & GD \\
\hline $\begin{array}{l}\text { Drive Sprocket } \\
\text { for Bucket } \\
\text { Elevator }\end{array}$ & BE3 & $\begin{array}{l}\text { Lathe } \\
\text { Machine }\end{array}$ & $\mathrm{BU}$ \\
\hline $\begin{array}{l}\text { Scrapper for } \\
\text { Conveyor }\end{array}$ & $\mathrm{CC} 1$ & ScrapMachine & SR \\
\hline $\begin{array}{l}\text { Drive Shaft for } \\
\text { Scrapper } \\
\text { Conveyor }\end{array}$ & $\mathrm{CC} 2$ & $\begin{array}{l}\text { Milling } \\
\text { Machine }\end{array}$ & MI \\
\hline \multirow[t]{2}{*}{$\begin{array}{l}\text { Drive Sprocket } \\
\text { for Scrapper } \\
\text { Conveyor }\end{array}$} & $\mathrm{CC} 3$ & Auto Weld & LO \\
\hline & & Trafo Weld & LS \\
\hline
\end{tabular}

\subsection{Formation of Group Technology Model with Rank Order Clustering (ROC)}

The steps of forming the model using the rank order clustering method are as follows:

For each row of the machine-component incidence, a matrix is given binary weights and calculated the decimal equivalent (weight). For example, the machinecomponent linkage value for row 1 is 011000 , the decimal equivalent value is: sorted the equivalent value of the rows from the largest order to the smallest (decreasing order), the matrix is transformed replacing rows and columns, sorted the equivalent value of the column from the largest order to the smallest (decreasing order), notice whether the ranking or sequence of equivalent values of rows and columns is different. Otherwise, the calculation stops, repeat steps 1 through 4 until the order or ranking of each element in rows and columns is no different.

\begin{tabular}{|c|c|c|c|c|c|c|c|c|c|c|c|c|c|c|c|c|c|}
\hline \multirow{2}{*}{ Mesin } & \multicolumn{17}{|c|}{ Part } \\
\hline & LR1 & $\mathrm{SCl}$ & $\mathrm{LR} 2$ & SC2 & $\mathrm{CCl}$ & BE1 & ST1 & SC5 & SC4 & LR4 & LRS & $\mathrm{SC} 3$ & $\mathrm{BE} 3$ & $\mathrm{CC} 3$ & LR3 & $\mathrm{BE} 2$ & $\mathrm{CC} 2$ \\
\hline$\overline{\mathrm{BLI}}$ & 1 & 1 & 1 & 1 & 1 & 1 & 1 & 0 & 0 & 0 & 0 & 0 & 0 & 0 & 0 & 0 & 0 \\
\hline LS1 & 1 & 1 & 1 & 1 & 0 & 0 & 0 & 0 & 0 & 0 & 0 & 0 & 0 & 0 & 0 & 0 & 0 \\
\hline PT11 & 1 & 1 & 1 & 1 & 0 & 0 & 0 & 0 & 0 & 0 & 0 & 0 & 0 & 0 & 0 & 0 & 0 \\
\hline BM1 & 1 & 1 & 1 & 0 & 0 & 0 & 0 & 0 & 0 & 0 & 0 & 0 & 0 & 0 & 0 & 0 & 0 \\
\hline $\mathrm{RO} 21$ & 1 & 0 & 0 & 0 & 0 & 0 & 0 & 0 & 0 & 0 & 0 & 0 & 0 & 0 & 0 & 0 & 0 \\
\hline $\mathrm{SCl}$ & 0 & 1 & 0 & 0 & 0 & 0 & 0 & 0 & 0 & 0 & 0 & 0 & 0 & 0 & 0 & 0 & 0 \\
\hline LS2 & 0 & 0 & 0 & 0 & 1 & 1 & 1 & 0 & 0 & 0 & 0 & 0 & 0 & 0 & 0 & 0 & 0 \\
\hline PT12 & 0 & 0 & 0 & 0 & 1 & 0 & 0 & 0 & 0 & 0 & 0 & 0 & 0 & 0 & 0 & 0 & 0 \\
\hline $\mathrm{PO2}$ & 0 & 0 & 0 & 0 & 1 & 1 & 0 & 0 & 0 & 0 & 0 & 0 & 0 & 0 & 0 & 0 & 0 \\
\hline BD2 & 0 & 0 & 0 & 0 & 1 & 1 & 0 & 0 & 0 & 0 & 0 & 0 & 0 & 0 & 0 & 0 & 0 \\
\hline GT2 & 0 & 0 & 0 & 0 & 1 & 0 & 0 & 0 & 0 & 0 & 0 & 0 & 0 & 0 & 0 & 0 & 0 \\
\hline IC2 & 0 & 0 & 0 & 0 & 0 & 0 & 1 & 0 & 0 & 0 & 0 & 0 & 0 & 0 & 0 & 0 & 0 \\
\hline $\mathrm{RO} 12$ & 0 & 0 & 0 & 0 & 0 & 1 & 0 & 0 & 0 & 0 & 0 & 0 & 0 & 0 & 0 & 0 & 0 \\
\hline $\mathrm{BO} 3$ & 0 & 0 & 0 & 1 & 0 & 0 & 0 & 1 & 1 & 1 & 1 & 1 & 1 & 1 & 0 & 0 & 0 \\
\hline BU3 & 0 & 0 & 0 & 0 & 0 & 0 & 0 & 1 & 1 & 1 & 1 & 1 & 1 & 1 & 1 & 1 & 1 \\
\hline PT23 & 0 & 0 & 0 & 0 & 0 & 0 & 0 & 1 & 1 & 0 & 0 & 0 & 0 & 0 & 1 & 1 & 1 \\
\hline MI3 & 0 & 0 & 0 & 0 & 0 & 0 & 0 & 1 & 0 & 0 & 0 & 0 & 0 & 0 & 1 & 1 & 1 \\
\hline SR3 & 0 & 0 & 0 & 0 & 0 & 0 & 0 & 0 & 0 & 1 & 1 & 1 & 1 & 1 & 0 & 0 & 0 \\
\hline
\end{tabular}

Fig. 2. The final matrix of ROC.

\subsection{Establishment of Group Technology Model with Similarity Coefficient (SC) Method}

The steps of forming a model using the rank order clustering method are as follows: place each machine in its own cell and determine the $\mathrm{SC}$ value by using the $\mathrm{Sij}$ equation, then specify the new SC value for the machine pair. Repeat this procedure until it scores the $\mathrm{SC}$ and the pairing machine. From this case, obtained the final matrix after 8 times the process of machine pair based on the coefficient of similarity. 


\begin{tabular}{|c|c|c|c|c|c|c|c|c|c|c|c|c|c|c|c|c|c|}
\hline Mesin & \multicolumn{17}{|c|}{ Part } \\
\hline $\mathrm{P}$ Pl & 0 & 0 & 1 & 1 & 0 & 0 & 0 & 0 & 0 & 0 & 0 & 0 & 0 & 0 & 0 & 0 & 0 \\
\hline BDI & 0 & 0 & 1 & 1 & 0 & 0 & 0 & 0 & 0 & 0 & 0 & 0 & 0 & 0 & 0 & 0 & 0 \\
\hline GTI & 0 & 0 & 0 & 1 & 0 & 0 & 0 & 0 & 0 & 0 & 0 & 0 & 0 & 0 & 0 & 0 & 0 \\
\hline IC1 & 0 & 0 & 1 & 0 & 0 & 0 & 0 & 0 & 0 & 0 & 0 & 0 & 0 & 0 & 0 & 0 & 0 \\
\hline $\mathrm{BLI}$ & 1 & 1 & 1 & 1 & 0 & 0 & 0 & 0 & 0 & 0 & 0 & 0 & 0 & 0 & 1 & 1 & 1 \\
\hline$L \gg 1$ & 1 & 1 & 1 & 1 & 0 & 0 & 0 & 0 & 0 & 0 & 0 & 0 & 0 & 0 & 0 & 0 & 0 \\
\hline PTII & 1 & 1 & 0 & 1 & 0 & 0 & 0 & 0 & 0 & 0 & 0 & 0 & 0 & 0 & 0 & 0 & 0 \\
\hline $\mathrm{BM1}$ & 1 & 0 & 0 & 0 & 0 & 0 & 0 & 0 & 0 & 0 & 0 & 0 & 0 & 0 & 0 & 0 & 0 \\
\hline PT22 & 0 & 0 & 0 & 0 & 1 & 0 & 0 & 0 & 1 & 1 & 1 & 0 & 1 & 0 & 0 & 0 & 0 \\
\hline $\mathrm{N} 12$ & 0 & 0 & 0 & 0 & 1 & 0 & 0 & 0 & 0 & 1 & 1 & o & 1 & 0 & 0 & 0 & 0 \\
\hline $\mathrm{BO} 2$ & 0 & 1 & 0 & 0 & 0 & 1 & 1 & 1 & 1 & 1 & 0 & 1 & 0 & 1 & 0 & 0 & 0 \\
\hline $\mathrm{BU} 2$ & 0 & 0 & 0 & 0 & 1 & 1 & 1 & 1 & 1 & 1 & 1 & 1 & 1 & 1 & 0 & 0 & 0 \\
\hline $\mathrm{SR2}$ & 0 & 0 & 0 & 0 & 0 & 1 & 1 & 1 & 0 & 0 & 0 & 1 & 0 & 1 & 0 & 0 & 0 \\
\hline L53 & 0 & 0 & 0 & 0 & 0 & 0 & 0 & 0 & 0 & 0 & 0 & 0 & 0 & 0 & 1 & 0 & 0 \\
\hline RO13 & 0 & 0 & 0 & 0 & 0 & 0 & 0 & 0 & 0 & 0 & 0 & 0 & 0 & 0 & 1 & 0 & 0 \\
\hline$L>4$ & 0 & 0 & 0 & 0 & 0 & 0 & 0 & 0 & 0 & 0 & 0 & 0 & 0 & 0 & 0 & 1 & 0 \\
\hline PT14 & 0 & 0 & 0 & 0 & 0 & 0 & 0 & 0 & 0 & 0 & 0 & 0 & 0 & 0 & 0 & 1 & 0 \\
\hline BM4 & 0 & 0 & 0 & 0 & 0 & 0 & 0 & 0 & 0 & 0 & 0 & 0 & 0 & 0 & 0 & 1 & 0 \\
\hline RO24 & 0 & 0 & 0 & 0 & 0 & 0 & 0 & 0 & 0 & 0 & 0 & 0 & 0 & 0 & 0 & 1 & 0 \\
\hline LSS & 0 & 0 & 0 & 0 & 0 & 0 & 0 & 0 & 0 & 0 & 0 & 0 & 0 & 0 & 0 & 0 & 1 \\
\hline PTIS & 0 & 0 & 0 & 0 & 0 & 0 & 0 & 0 & 0 & 0 & 0 & 0 & 0 & 0 & 0 & 0 & 1 \\
\hline BMS & 0 & 0 & 0 & 0 & 0 & 0 & 0 & 0 & 0 & 0 & 0 & 0 & 0 & 0 & 0 & 0 & 1 \\
\hline $\operatorname{scs}$ & 0 & 0 & 0 & 0 & 0 & 0 & 0 & 0 & 0 & 0 & 0 & 0 & 0 & 0 & 0 & 0 & 1 \\
\hline
\end{tabular}

Fig. 3. The final matrix of SC.

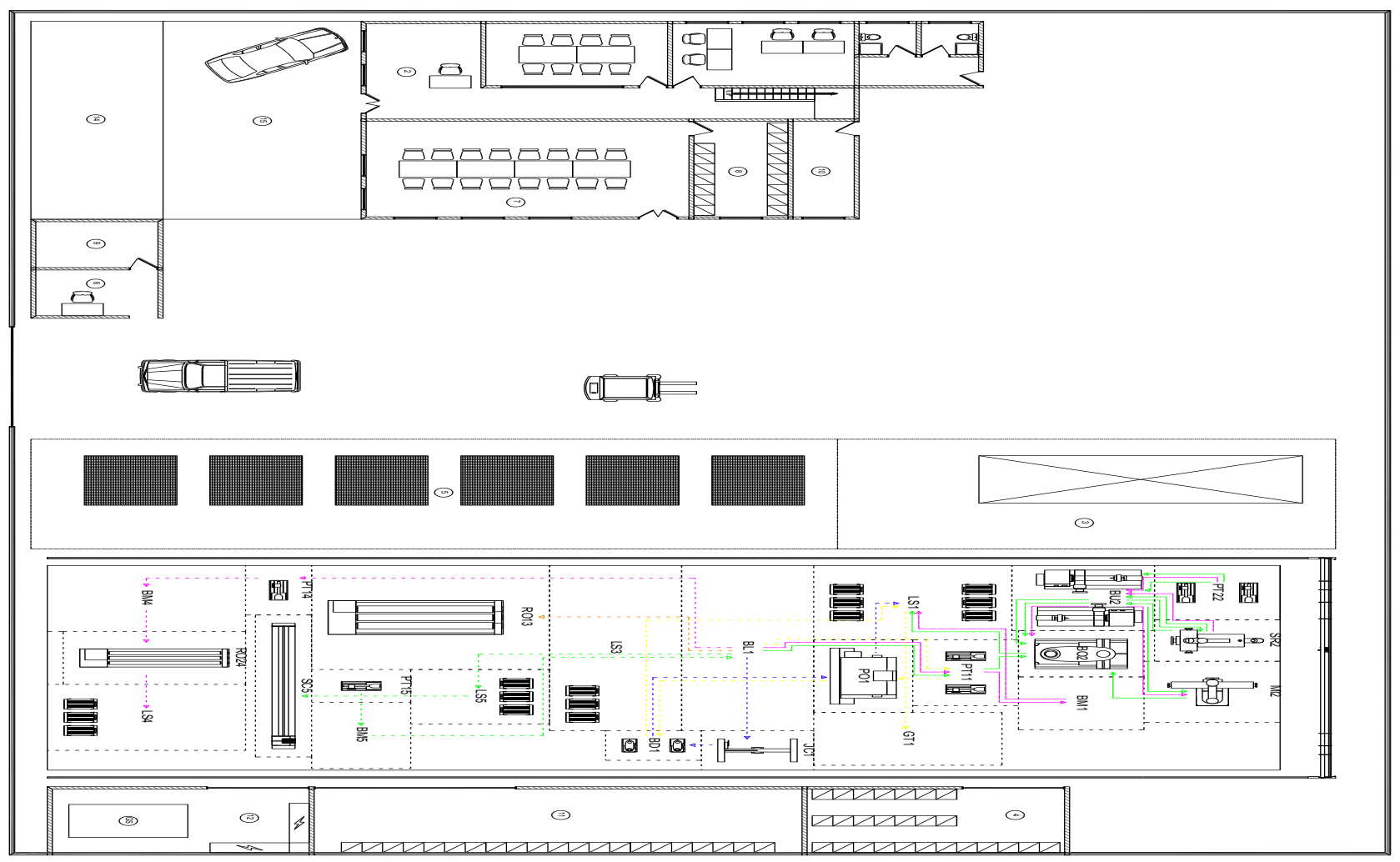

Fig. 4. Proposed layout.

\subsection{Discussion}

Previous research has been carried out in handling material handling at boiler manufacturing companies where the design uses CRAFT method and can minimize boiler manufacturing time by 1598 minutes per product or give an efficiency effect of $8.95 \%$ [9]. Facilitation of facility layout to service industry at the university also has been done to increase utility use of room which effective use method of CORELAP and impact increase by $14,98 \%$. The facility layout redesign should be done to improve room space efficiency and material handling costs can be minimized [7].

\footnotetext{
* Corresponding author: anitakembaren $@$ unprimdn.ac.id
}

To improve the layout of facilities on the production floor of the manufacture of machinery and spare parts of palm oil is based on the distance between the machine and the frequency of material handling. Determining the total distance traveled during the production process and the length of production time from the initial layout and the proposed layout for each product produced. In the data processing above the total distance is calculated from the initial conditions, ROC, and SC. As we can see in Table 2 the total material handling is calculated using $\mathrm{SC}$ because it obtains the minimum distance. 
Table 2. Distance calculation and material handling moment before and after designing.

\begin{tabular}{|r|r|r|r|}
\hline \multirow{2}{*}{ Produk } & \multicolumn{3}{|c|}{ Material Handling Moment } \\
\cline { 2 - 4 } & $\begin{array}{c}\text { Initial } \\
\text { Layout }\end{array}$ & $\begin{array}{c}\text { Layout } \\
\text { ROC }\end{array}$ & \multicolumn{1}{c|}{ Layout SC } \\
\hline LR1 & $31.287,64$ & $10.554,71$ & $13.921,35$ \\
\hline LR2 & 16.533 & $8.065,8$ & $4.658,4$ \\
\hline LR3 & $5.572,8$ & $1.254,6$ & $2.514,6$ \\
\hline LR4 & 2.637 & $1.648,8$ & 821,7 \\
\hline LR5 & $1.325,25$ & 481,05 & 452,7 \\
\hline ST1 & $3.833,6$ & $1.299,2$ & $1.209,6$ \\
\hline SC1 & $9.531,9$ & $10.621,8$ & 8.505 \\
\hline SC2 & $3.057,45$ & $3.437,4$ & $1.606,5$ \\
\hline SC3 & 500,65 & 181,73 & 171,02 \\
\hline SC4 & $2.269,5$ & 522,75 & 398,82 \\
\hline SC5 & 1.068 & 272,88 & 485,76 \\
\hline BE1 & $16.283,3$ & $9.143,8$ & $6.726,85$ \\
\hline BE2 & 743,04 & 167,28 & 335,28 \\
\hline BE3 & $1.155,84$ & 346,08 & 554,4 \\
\hline CC1 & $22.017,6$ & 12.852 & $8.409,6$ \\
\hline CC2 & 557,28 & 125,46 & 251,46 \\
\hline CC3 & 866,88 & 259,56 & 415,8 \\
\hline Total & $119.240,73$ & $61.234,9$ & $51.438,84$ \\
\hline
\end{tabular}

When we calculate the time duration needed for a cycle of production, ROC is the minimum cycle time with 1,688 minutes whether using SC, we get a little difference with 1,688.5 minutes. In this research, still, will prefer SC to be used since it is not so different.

Table 3. Comparison of production time duration.

\begin{tabular}{|r|r|r|r|}
\hline \multirow{2}{*}{ Produk } & \multicolumn{3}{|c|}{ Production Time (minute) } \\
\cline { 2 - 4 } & \multicolumn{1}{|c|}{$\begin{array}{c}\text { Initial } \\
\text { Layout }\end{array}$} & $\begin{array}{c}\text { Layout } \\
\text { ROC }\end{array}$ & \multicolumn{1}{c|}{ Layout SC } \\
\hline LR1 & $1.729,5$ & 1.688 & $1.688,5$ \\
\hline LR2 & 255,5 & 206 & 208 \\
\hline LR3 & 87,5 & 68 & 71 \\
\hline LR4 & 59,5 & 47,5 & 37 \\
\hline LR5 & 34 & 23 & 21 \\
\hline ST1 & 273 & 217 & 217 \\
\hline SC1 & 104 & 107 & 105 \\
\hline SC2 & 33,5 & 41 & 29 \\
\hline SC3 & 30,5 & 20 & 18,5 \\
\hline SC4 & 90 & 58 & 56 \\
\hline SC5 & 110 & 80,5 & 85 \\
\hline BE1 & 39,5 & 30 & 29 \\
\hline BE2 & 87 & 68 & 70 \\
\hline BE3 & 25,5 & 19 & 20 \\
\hline CC1 & 40,5 & 34 & 29 \\
\hline
\end{tabular}

\section{Conclusions}

In the current production floor layout, the total material handling moment is $119,240.73$ meters of displacement per year. From the results of design analysis with the method of Similarity Coefficient (SC), it can be concluded that the method is a better layout design to be applied. In the design layout better proposal using SC method where the total material handling obtained is smaller that is $51.438,84$ meter displacement per year.

With the application of SC layout method to current layout can reduce total material handling moment by $67,801,89$ meter displacement per year. The decrease of material transfer moment in the proposed layout on the production floor with SC method reaches 56,86\%. compared to the initial layout. The layout design using $\mathrm{SC}$ method provides total process time reduction for all products of 338 minutes. For company facilities iteration results BLOCPLAN algorithm shows the best layout is on 15 th iteration with the value of proximity between facilities in the company (Adjency Score) of 0,5317.

The analysis of company facility design with BLOCPLAN Algorithm gives a result that level of proximity layout proposal better than the initial condition where the difference of adjency score reach 0,1666 .

The authors would like to thank the Faculty of Technology and Computer Science of Universitas Prima Indonesia for support to carry out the research.

\section{References}

1. H. Nasution, I. Budiman, and A. Salim, The cost analysis of material handling in Chinese traditional praying paper production plant, IOP Conf. ser.: mater. sci. Eng., 309012044 (2018).

2. A. James, PLMH, 3, John Willey and Sons, Inc, (1977)

3. R. Ampuh Hadiguna, Tata Letak Pabrik, CV. Andi Offset (2008)

4. H. Rahmad, PUSFLMW, Universitas Trunojoyo, Madura (2014)

5. M. Richard., PPL, McGraw- Hill Book Company, Inc, (1955)

6. Kitriastika, Vincentia., A Redesign Layout to Increase Productivity of a Company, Swiss German University, (2013)

7. A. C Sembiring, I Budiman, A Mardhatillah, U P Tarigan, and A Jawira, An application of CORELAP algorithm to improve the utilization space of the classroom, J. Phys.: Conf. Ser., 1007 012026 (2018)

8. A. C Sembiring, Perancangan Ulang Tata Letak Pabrik untuk Meminimalisasi Material Handling di PT. Atmindo, Universitas Sumatera Utara, (2012)

9. A. C Sembiring, Perancangan Ulang Tata Letak Pabrik untuk Meminimalisasi Material Handling pada Industri Pembuat Boiler, Prosiding SNTI, 7, C242-247,(2017)

10. Drira, A., Pierreval, H., Gabouj, S.H.,. Facility Layout Problems: A Survey, Annual Reviews in Control, 255-267, (2007)

11. A. J. Khan, Tidke, D.J., Designing Facilities Layout for Small and Medium Enterprises, International Journal of Engineering Resesarch and General Science, pp. 1-8, (2013)

12. M. Matalycki., Kiturko O., Basiewicz N., Application of HM-networks in problems of transport logistics, Scientific Research of the Institute of Mathematics and Computer Science, 153-172, (2010) 
13. G. Tamal, and P. K., Effective Clustering Method For Group Technology Problems: A Short Communication, India, e-Journal of Science and Technology (e-JST), (2011)

14. G. Mikell P., Automation, Production System and Computer Integrated Manufacturing, New Jersey, Prentice-Hall Inc, (2001)

15. Setiawati, L., Production Facility Layout Improvements using Blocplan Algorithm. Industrial Engineering Journal Bung Hatta University, Volume 1(2), 2, 206-216, (2012) 